\title{
Democratization in the World and Challenges to European Democracies
}

\author{
Tatu Vanhanen \\ (University of Helsinki, Finland)
}

\section{Content >}

I. Key Characteristics of Democracy

II. Global Regularities in Democratization
III. Challenges to European Democracies

IV. Conclusion

- Key Words: European democracy, EU, electoral participation, global regularities, cultural boundaries, democratic institutions

\section{【ABSTRACT 】}

The idea of this paper is to examine challenges to European democracies compared to the state of democracy in the other parts of the world. This exploration is based on the argument that, because of our common human nature, the basic characteristics of democracy remain the same across cultural boundaries, which makes global comparisons sensible. The existing democracies differ from each other in the extent to which they approach the ideal goals of democratization. European countries seem to have attained a higher level of democratization than what has been attained in the other parts of the world, but it is easy to see various deficits in all European democracies, too. They provide challenges to European democracies. Such challenges concern, for example, the unfinished process of democratization in former European socialist countries, the need to maintain a high level of electoral participation, the increasing tendency to resort to referendums, the means to accommodate non-European migrants into European societies, and the appropriate form of democracy for the European Union. These challenges are discussed in this paper.

* A short version of paper presented at the conference on Democracy in Asia, Europe, and the World: Toward a Universal Definition? in Panel 4: Challenges to Democracy in Europe and Asia, 3-4 June, 2004, Seoul, Korea. 


\section{Key Characteristics of Democracy}

Challenges to democracies arise from perceptions that the existing forms of democracy do not satisfy some requirements of democracy, that there are shortcomings requiring corrections, or that new problems have emerged. Shortcomings are related to the accepted ideal of democracy, but what is the accepted ideal of democracy? What are the key characteristics of democracy to which perceived shortcomings and deficits are related? Democracy has long been, as Jean Blondel says (2004), among the most contested concepts in political science and political philosophy, and a universally-accepted view of democracy has not yet been obtained, but I am tended to argue that at least a universally-accepted view of some key characteristics of democracy can be obtained. Let us start from descriptions of such key characteristics.

Robert A. Dahl (1971: 1-9) says that "a key characteristic of a democracy is the continuing responsiveness of the government to the preferences of its citizens, considered as political equals." He would like to reserve the term "democracy" for a political system "one of the characteristics of which is the quality of being completely or almost completely responsive to all its citizens." In practice, of course, it is impossible for any political system to satisfy these requirements of democracy, but they provide a yardstick against which to measure the achievements of existing democracies. It is impossible for any political system to attain Dahl's standard of democracy for the simple reason that because of human diversity citizens are not equals in politics and their interests and preferences contradict each other, which makes it impossible for a government to be "completely or almost completely responsive to all its citizens." Dahl complements his concept of full democracy by a detailed list of institutional guarantees of democracy and concludes that they constitute "two somewhat different theoretical dimensions of democratization." These two dimensions are public contestation and right to participate in elections and office. They can be used to measure the level of democratization in a country (cf. Sorensen 1993: 9-16; Linz and Stepan 1996).

There has been debate about "Asian values" and democracy. It has been implied that democracy with individual human rights might not be in harmony with "Asian values," but Takashi Inoguchi and Edward Newman (1997: 7) point out that such arguments "are too easily a fa?ade behind which authoritarian leaders deny human rights and opposition" (cf. Khong 1997; for definitions of democracy, see also Inoguchi et al. 1998; Marsh et al. 1999; Lijphart 1999; Schmidt 2000).

UNDP's Human Development Report 2002 (2002: 4) argues that in many countries "a central challenge for deepening democracy is building the key institutions of democratic 
governance." The key institutions cover (1) a system of representation, with well-functioning political parties and interest associations; (2) an electoral system that guarantees free and fair elections as well as universal suffrage; (3) a system of checks and balances based on the separation of powers, (4) a vibrant civil society, able to monitor government and private business - and provide alternative forms of political participation; (5) a free, independent media; and (6) effective civilian control over the military and other security forces.

My explanation for the key characteristics of democracy is derived from the assumption that all human populations share the similarities of human nature and from a Darwinian interpretation of politics. By the "similarities of human nature," I mean that we share common behavioral predispositions engraved in our genome. They constrain human behavior and provide explanations for observed universal regularities in politics (see Vanhanen 1992).

A Darwinian interpretation of politics provides an evolutionary explanation for the emergence of some key characteristics of democracy. The theory of evolution by natural selection explains why the struggle for survival and scarce resources is inevitable in nature. Politics can be interpreted as a forum and expression of the universal struggle for existence in nature. The permanent scarcity of some important resources and the need to distribute them by some means explains the necessity to struggle for power in politics. In this struggle, we are tended to resort to all available resources that can be used as sources of power. My point is that there is a strong connection between human politics and the general struggle for existence in nature and that the evolutionary theory explains why it must be so. Human desire for power and for the fruits of power can be assumed to be constant, but in practice all people and their groups do not have the same chances to get power and the fruits of power because the abilities of people vary greatly and because the resources used as sources of power are not equally distributed. The distribution of political power depends ultimately on the degree of resource distribution. Those controlling most effective power resources have better chances to get power than those whose power resources are weak. Democracy emerges in a situation in which power resources have become so widely distributed that no group is any longer able to suppress its competitors or to maintain its hegemony. Thus democracy emerges as a compromise between powerful competitors. This compromise is institutionalized by constitutional rules of game that regulate legal competition for power positions and the sharing of power (see Vanhanen 1992: 18-27; 2003: 25-29). 


\section{Global Regularities in Democratization}

I have tested my evolutionary resource distribution theory of democratization by empirical evidence on the degree of resource distribution and on the level of democratization in single countries. Two simple political variables are used to measure two crucial dimensions of democracy: the degree of competition and the degree of participation. The Competition variable indicates the percentage of the smaller parties of the votes or of the seats in parliamentary and/or executive elections. The value of Competition variable is calculated by subtracting the percentage of the largest party from 100 . The participation variable indicates the percentage of the total population who voted in the same elections and also the impact of referendums in such a way that each national referendum increases Participation by five percentage points and each state referendum by one percentage point for the year when referendum was held. The upper limit for the impact of referendums in the Participation variable is 30 percent. The upper limit for both basic variables is 70 percent. The two basic measures of democracy are combined into an Index of Democratization (ID) by multiplying Competition and Participation and by dividing the product by 100 . Because of multiplication, ID gets high values only if the values of both basic variables are high. The two basic measures of democracy can be used to separate democracies from nondemocracies by defining threshold values of democracy. In my latest study (Vanhanen 2003), the threshold values of democracy are 30 percent for Competition and 20 percent for Participation. Data on political variables over the period 1810-2002 are presented in the FSD1289 Measures of Democracy 1810-2002 dataset and in the Polyarchy Dataset. In this paper, data on the measures of democracy are from the year 2002.

It is much more difficult to measure the relative degree of resource distribution than the degree of democratization for the reason that many types of resources are used as sanctions in the struggle for power. Five variables are used to measure the relative distribution of economic and intellectual power resources from different perspectives:

1. Students in universities per 100,000 inhabitants as a percentage from 4,000 students per 100,000 inhabitants (Students\%).

2. Literates as a percentage from the adult population.

3. The area of family farms as a percentage of the total area of holdings (FF).

4. The degree of decentralization of mainly nonagricultural economic power resources (DD).

5. Real Gross Domestic Product per capita as a percentage from 25,000 dollars per capita in 1998 (Real GDP\%). These are purchasing power parity dollars. 
The five explanatory variables can be used separately in the statistical analysis, but because they are intended to be indicators of the same theoretical explanatory factor ? resource distribution ? I combined them into indices. The best combination is the Index of Power Resources (IPR), which is based on the four first variables (see Vanhanen 2003).

The operationalization of the measures of democracy and of resource distribution made it possible to transform my theoretical arguments into research hypotheses. The principal research hypothesis is: The measures of democracy are positively correlated with the measures of resource distribution. The hypothesis was tested in the group of 170 contemporary countries, which group covers all independent countries whose population in 2000 was more than 200,000 inhabitants. Correlation and regression analyses were used to test the hypothesis.

The results of correlation analysis show that all correlations between the measures of democracy and the degree of resource distribution are positive as hypothesized and that nearly all correlations are moderate or strong (Vanhanen 2003). The strongest correlation 0.839 is between IPR and ID-2002. It means that the Index of Power Resources explains statistically 70 percent of the variation in the level of democratization. Regression analysis is used to show the results at the level of single countries. Figure 1 illustrates the results of regression analysis of ID-2002 on IPR for single countries.

[Figure 1] The results of regression analysis of ID-2002 on IPR for single countries in the group of 170 countries

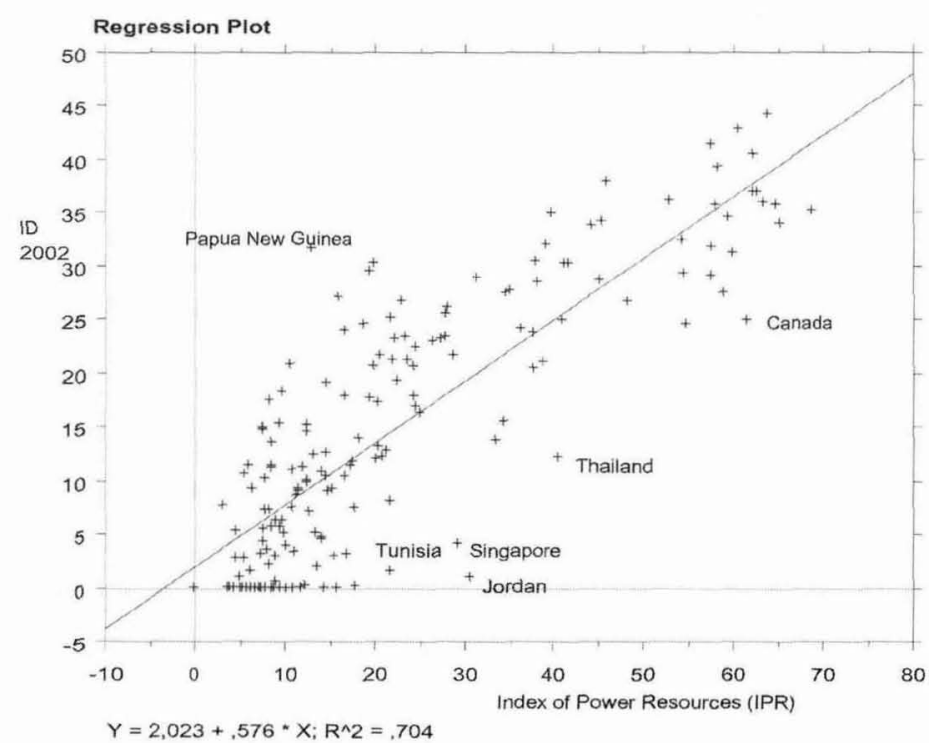


We can see from Figure 1 that most countries are relatively close to the regression line, which means that their actual level of democratization does not differ much from the level predicted on the basis of the degree of resource distribution (IPR). This indicates, according to my interpretation, that similar types of democratic institutions have tended to emerge in all parts of the world in similar environmental conditions (the degree of resource distribution). It is difficult to find any civilizational differences from the relationship between IPR and ID, whereas there are deviating countries within all civilizational and regional groups.

Another way to examine the assumption about the similarities in the process of democratization is to compare the means of variables as well as residuals by regional groups (Table 1). If the assumption is correct, the means of ID residuals should be approximately the same for all regional groups.

[ Table 1] The means of IPR, ID, Competition, Participation, and ID residuals by regional groups in the group of 170 countries

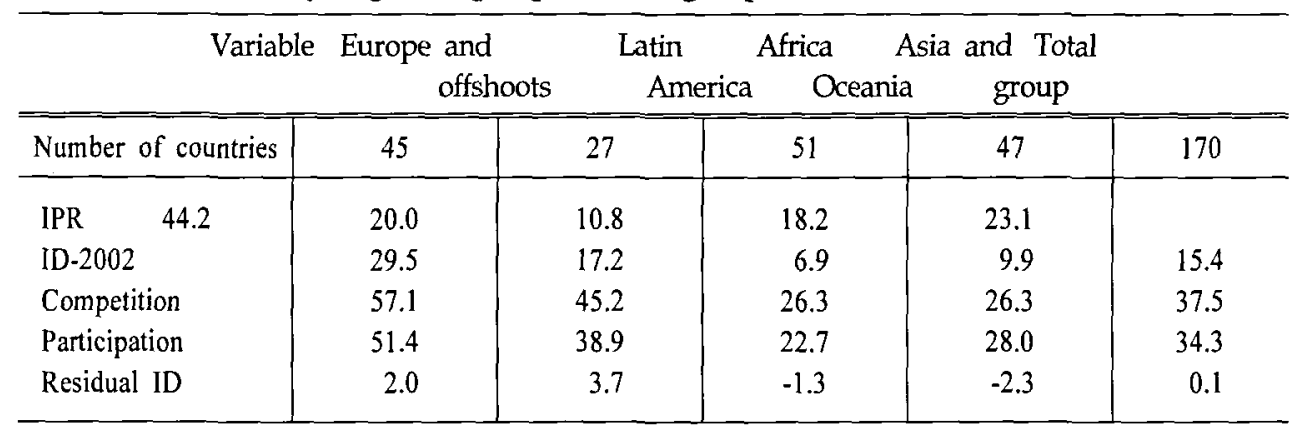

Table 1 shows that the level of democratization (ID) is much higher in Europe than in any other regional group, and so is the degree of resource distribution (IPR). The means of ID and IPR are lowest in the group of African countries. The mean of ID is considerably lower for the group of Asian and Oceanian countries than for the group of Latin American and Caribbean countries, although the mean of IPR is only slightly higher for the Latin American group. The same difference is in the means of ID residuals. For the Latin American group the mean of ID residuals is clearly positive (3.6) and for Asian countries clearly negative $(-2.3)$. This difference implies that we could expect some decrease of ID in Latin America and some increase of ID in the group of Asian and Oceanian countries. However, differences in the means of residuals between regional groups are relatively small. 


\section{Challenges to European Democracies}

Although the level of democratization in Europe is higher than in any other region of the world, it does not mean that European democracies were already perfect ones. There are various deficits in all existing democracies, which deficits provide challenges to improve institutions of democracy. As Jan Zielonka (2004: 32) says, democracy "at the level of nation-state is imperfect in both old and new EU member states."

Electoral data disclose two particular shortcomings of democracy in Europe: (1) democratic institutions have not yet become consolidated in several former socialist countries and (2) the level of electoral participation varies greatly and is relatively low in some countries. Other challenges to European democracies arise from the need (3) to resort to referendums much more frequently than previously, (4) to adapt democratic institutions to the needs of multi-cultural societies and to accommodate non-European immigrants to European societies, and (5) to decide on the democratic framework of the European Union.

\section{Unfinished process of democratization in former socialist countries}

The European group includes 21 former socialist countries; nine of which are former Soviet republics. All of them have established democratic institutions, but the process of democratization has been uneven. Democratic institutions seem to have become best stabilized in Bulgaria, Croatia, Czech Republic, Estonia, Hungary, Latvia, Lithuania, Poland, Romania, Slovakia, and Slovenia. In these countries the level of democratization is relatively high and it is approximately in balance with the degree of resource distribution (IPR). The swift and efficient democratization in these countries implies that the communist one-party rule was unnatural in their social and cultural circumstances and that it was based only on the use and threat of violent means of control just like the Nazi regime in Germany in the period 1933-1945. The collapse of the communist system in the Soviet Union in 1989-91 opened the gates of democratization and led quickly to the demolition of socialist economic and political structures.

In the other ten countries the process of democratization has not been as smooth and successful, although nearly all of them are above the minimum threshold of democracy (cf. Bremmer and Taras 1997; Stepan and Linz 1998; Samuels 2003). In Albania, there have been electoral irregularities and boycotts of parliament. In Armenia, the party system is fragmentary, and there have been political violence. In Belarus, the persistence of socialist economic sructures supports the hegemony of President Lukashenka. Bosnia \& 
Herzegovina suffers from the consequences of the ethnic civil war. Georgia, Macedonia, Moldova, and Serbia and Montenegro also suffer from ethnic conflicts. In Russia, the level of democratization (ID) declined in the 2003-2004 parliamentary and presidential elections and it is now approximately in balance with Russia's relatively low level of resource distribution (IPR). In Ukraine, the level of democratization (ID) is still much higher than expected on the basis of IPR. A great challenge to the institutions of democracy in Ukraine is to strengthen the socio-economic foundation of democracy by structural economic reforms.

\section{The challenge of electoral participation}

The level of electoral participation has risen considerably in European countries since the 19th century and even since the first half of the 20th century, but its rise seems to have stagnated since the $1980 \mathrm{~s}$ in old European democracies. Because democracy presupposes popular participation in elections, the stagnation of electoral participation provides a challenge to old European democracies. Has electoral participation already reached its culmination? What could be done to increase electoral participation?

Data on the degree of electoral participation in 20 old European democracies over the period 1950-2002 (see FSD1289 Measures of Democracy 1810-2002; the Polyarchy Dataset) show that the average level of electoral participation has really stagnated after 1980, although it is still at the average level of the period 1950-2002 and nearly two times higher than in 1920. The stagnation of electoral participation raises the question about the maximum level of electoral participation. Because minors under the voting age (18 years) constitute approximately 18-25 percent of the population in these countries and because some people are always unable to vote for various reasons, it would be difficult to raise the degree of electoral participation higher than to 70 percent of the total population. The average level of electoral participation has been 52-55 percent since 1980. The gap between 52 percent and potential 70 percent is 18 percentage points. I think that human diversity provides an explanation for this gap. Some people (perhaps 10-15\%) are simply not sufficiently interested in politics. Therefore, $65-70$ percent of the total population may represent the maximum level of electoral participation which is possible to achieve in free elections.

Some countries (Austria, Denmark, Italy, and Sweden) have already achieved or approached that maximum level in some elections. On the other hand, countries like Canada, France, Ireland, Luxembourg, Switzerland, and the United States are clearly below the average level of electoral participation. These differences seem to be at least partially 
due to differences in electoral systems, which differ from each other in the degree of proportionality or disproportionality in their translation of votes into seats (Lijphart 1999: 144). The level of electoral participation is systematically lower in the countries using plurality and majority formulas (Canada, France, Ireland, New Zealand, United Kingdom, and the United States) than in the countries using proportional electoral systems. Consequently, it is justified to argue that the transition to a proportional electoral system would raise the level of electoral participation in these countries (see also Nohlen 1978; Rose 1980; Grofman and Lijphart 1986).

\section{The challenge of direct democracy}

Referendums represent the principal form of direct democracy in contemporary world. In Switzerland and the United States, referendums have been used regularly since the 19th century. Referendums have been frequent also in Australia and to a lesser extent in countries like New Zealand, Denmark, France, Ireland, and Italy, but in the other European countries referendums were relatively rare until the 1980s and even more infrequent in the other parts of the world (see Butler and Ranney 1978, 1994; Lijphart 1984).

Since the 1980s referendums have become more frequent in European democracies. Arend Lijphart (1984) connects referendums to direct democracy and explores the reasons for the use of referendums, but he did not find any satisfactory explanation. I think that referendums represent a new dimension of democratization. Democracy is not a closed system. As George Sorensen (1993: 11) says, there is "still plenty of room for the development of different variations of models of democracy." Referendums provide to ordinary people means for direct participation in political decision-making. Because the average level of representative democracy in Europe is higher than in other parts of the world, it is not surprising that this new dimension of democracy emerged in Europe. I think that referendums enhance the quality of democracy.

Butler and Ranney (1994: ix) observe that in Western Europe the evolution of the European Community has increased the use of referendums, and in Eastern Europe, following the disintegration of the Soviet Union, boundaries, sovereignties, and governing institutions have been extensively tested by referendums. It is a challenge to European democracies to combine the institutions of representative democracy with the popular pressure to direct democracy through referendums. A partly new form of democracy may emerge from this combination. Other European democracies may gradually follow the example of Switzerland. 


\section{The challenge of a multi-cultural society}

Both ethnically and culturally homogeneous and heterogeneous European and European offshoot countries are democracies, but democracies face additional problems in multi-cultural and ethnically divided societies. How to adapt democratic institutions to the requirements of such societies? Further, how to solve inevitable interest conflicts in ethnically or culturally heterogeneous societies democratically? Should democracies grant citizenship and equal rights to all people living in a country, or is it justified to deny citizenship and equal rights from some groups? It is obvious that European democracies have not yet been able to solve these problems satisfactorily. Various conflicts, demonstrations, ethnic terrorism, and alienation from politics express dissatisfaction.

All European societies are ethnically and culturally to some extent heterogeneous (see Vanhanen 1999), but there is great variation in the nature and degree of heterogeneity. Some ethnic and cultural cleavages are old ones, and some others have emerged more recently. International migration of people is changing and has already changed the national character of several European societies. The problem is how to accommodate non-European migrants to European societies. It is not an easy task. Should the migrants retain their ethnic and cultural separateness, or should European societies try to assimilate them into European cultural patterns and to merge them biologically to European populations by mixed marriages? These are still open questions.

It is a challenge to European democracies to solve their ethnic and cultural problems by democratic means, but it is not yet clear how this can be made. The uncertainty concerns principally the recent non-European migrants. Should they be culturally assimilated to European societies, or should European societies transform themselves multi-cultural ones? Biological mixing between migrants and Europeans would solve the problems most effectively, but it is a slow process. However, it has already started (see Wells 2002). Iren?us Eibl-Eibesfeldt (2004) emphasizes that "multicultural societies are frequently torn apart by ethnic discord in the political and economic realms" (p. 286). Historical experience shows that it has been difficult to establish and maintain harmonious multi-cultural societies. Therefore he recommends the assimilation of migrants to European societies and criticizes politicians who "seek to persuade whole populations to open the gates to unrestricted immigration." He says that this "amounts to persuasion to ethnocide" (p. 288).

\section{Democracy in the European Union}

The European Union is said to be based on commonly shared values, which include, 
according to Vaclav Havel (2004), "respect for the individual, his freedoms, rights and dignity; the principle of solidarity; the rule of law and equality before the law; protection of minorities; democratic institutions; separation of the powers of the legislature, executive and judiciary; plurality of the political system; inviolability of private ownership; private enterprise and the market economy; and the development of civil society." These are not only European values; to some extent they are shared by many other nations. Unfortunately shared values alone do not tell us how democracy should be adapted to the European Union and to its relations with its members.

Disagreements concern especially the nature and powers of EU institutions, the sharing of power between small and big countries in EU institutions, the extent to which the composition of EU institutions should be based on democratic elections, the sovereignty of member countries, and the distribution of power between the European Union and its member countries (cf. Plattner 2003). It is a challenge to European democracies to solve these disagreements and invent how democratic principles can be applied to the government of the Union, which is not a state, a federation, or a confederation. Jan Zielenka (2004) says that it is a kind of neo-medieval empire. Zielenka suspects that democracy "can hardly work in a complicated if not impenetrable system of multi-layered arrangements that work at different speeds and are run by shifting groups of unidentified and unaccountable people" (p. 29). He argues that the neo-medieval scenario for the enlarged EU is pregnant with uncertainties and risks and that the attempt to create a core group within the larger Union would only make things worse. He thinks that the Union clearly suffers from a "democratic deficit" and that enlargement makes the deficit deeper.

Yves M?ny (2003: 70) says that the "EU represents an ambitious but still imperfect attempt to construct a democracy beyond the borders of a nation-state." I agree. It seems to me that, from the perspective of democratization, something new is emerging in Europe as a consequence of the European Union. It concerns the sharing of powers between national and supranational democratic institutions and an attempt to create a new type of political community. This is an exciting incubation time in Europe.

\section{Conclusion}

I have analyzed some challenges to European democracies from a comparative perspective, by relating the problems and deficiencies of European democracies to the state of democracy in the other parts of the world. My central argument is that democracies tend to face similar challenges in all parts of the world because the key characteristics 
and goals of democracy are more or less the same. According to my interpretation, the idea of democracy remains the same because democracy emerges as a compromise between powerful contenders. Democratic institutions and the rules of game represent the institutionalized forms of this compromise, and a sufficient level of resource distribution is needed to maintain this compromise. There are differences in the institutions of democracy and in the style of democracy as Inoguchi (1998) has shown, but my point is that despite such civilizational differences, the key characteristics of democracy remain the same because they are based on our common human nature. Everywhere democracy presupposes free and legal competition for power posititions and extensive participation of citizens.

My review of challenges to European democracies illustrates the nature of some democratic deficits and the field of new problems that challenge the ability of European democracies to find satisfactory solutions. The process of democratization has not yet ended. New problems challenge European democracies to adapt their existing democratic institutions to changing environmental conditions and to invent new forms of democracy at the supranational level of the European Union. This is really an exciting time of democratic incubation in Europe. 


\section{References}

Blondel J (2004) Towards a universal definition of democracy? Email circular.

Bremmer I, Ray R (eds) (1997) New States, New Politics: Building the Post-Soviet Nations. Cambridge University Press, Cambridge.

Butler D, Ranney A (eds) (1978) Referendums: A Comparative Study of Practice and Theory. American Enterprise Institute, Washington, D.C.

Butler D, Ranney A (1994) Theory. In: Butler D, Ranney A (eds) Referendums around the World: The Growing Use of Direct Democracy. The Macmillan Press, London, pp. 11-23.

Butler D, Ranney A (eds) (1994) Referendums around the World: The Growing Use of Direct Democracy. The Macmillan Press, London.

Dahl R A. (1971) Polyarchy: Participation and Opposition. Yale University Press, New Haven and London.

Eibl-Eibesfeldt I (2004) Ethnicity, the Problem of Differential Altruism, and International Multiculturalism. In: Salter F K (ed.) Welfare, Ethnicity, and Altruism: New Findings and Evolutionary Theory. Frank Cass, London, pp. 283-291.

FSD1289 Measures of Democracy 1810-2002 (2004). Finnish Social Science Data Archive, University of Tampere. Online: <http://www.fsd.uta.fi/english/data/catalogue/FSD 1289/meF1289e.html>.

Grofman B, Lijphart A (eds) (1986) Electoral Laws and their Political Consequences. Agathon Press, New York.

Havel V (2003) A new impetus for old Europe. In: The World in 2004. The Economist, London, p. 34.

Inoguchi T, Newman E (1997) Introduction: 'Asian values' and Democracy in Asia. In: 'Asian values' and Democracy in Asia. Proceedings of a Conference Held on 28 March 1997 at Hamamatsu, Shizuoka, Japan. The United Nations University. Tokyo, pp. $1-10$.

Inoguchi T (1998) Asian-style democracy? In: Inoguchi T, Newman E, Keane J (eds) The Changing Nature of Democracy. United Nations University Press, Tokyo, pp. 173-183.

Inoguchi T, Newman E, Keane J (eds) (1998) The changing nature of democracy. United Nations University Press, Tokyo.

Khong C. O. (1997) Asian values: The Debate Revisited. In: 'Asian values' and Democracy in Asia. Proceedings of a Conference Held on 28 March 1997 at Hamamatsu, Shizuoka, Japan. The United Nations University, Tokyo, pp. 11-17. 
Lijphart A. (1984) Democracies: Patterns of Majoritarian and Consensus Government in Twenty-One Countries. Yale University Press, New Haven and London.

Lijphart A (1999) Patterns of Democracy: Government Forms and Performance in Thirty-Six Countries. Yale University Press, New Haven and London.

Linz J J, Stepan A (1996) Problems of Democratic Consolidation: Southern Europe, South America, and Post-Communist Europe. The Johns Hopkins University Press, Baltimore and London.

Marsh I, Blondel J, Inoguchi T (eds) (1999) Democracy, governance, and economic performance: East and Southeast Asia. United Nations University Press, Tokyo.

Mény Y (2003) The Achievements of the Convention. Journal of Democracy 14(4):57-70. Nohlen D (1978) Wahlsysteme der Welt: Daten und Analysen. R. Piper \& Co, Manchen. Plattner M F (2003) Competing Goals, Conflicting Perspectives. Journal of Democracy $14(4): 42-56$.

The Polyarchy Dataset: Vanhanen's index of democracy. International Peace Research Institute, Oslo. Online: <http://www.prio.no/cwp/vanhanen/>.

Rose R (ed.) (1980) Electoral Participation: A Comparative Analysis. SAGE Publications, Beverly Hills.

Samuels R (2003) Comparing Theories of Democratic Support: Lessons from Post-Communist Europe. Democratization 10(2):105-120.

Schmidt M G (2000) Demokratietheorien. Leske + Budrich, Opladen:.

Sorensen G (1993) Democracy and Democratization: Processes and Prospects in a Changing World. Westview Press, Boulder.

Stepan A, Linz J J (1998) Post-communist Europe: Comparative reflections. In: Inoguchi

T, Newman E, Keane J (eds) The Changing Nature of Democracy. United Nations University Press, Tokyo, pp. 184-212.

UNDP (United Nations Development Programme) (2002) Human Development Report 2002: Deepening democracy in a fragmented world. Oxford University Press, New York.

Vanhanen T (1999) Ethnic Conflicts Explained by Ethnic Nepotism. Research in Biopolitics, Volume 7. Jai Press, Stamford, Connecticut.

Vanhanen T (1992) On the Evolutionary Roots of Politics. Sterling Publishers, New Delhi. Vanhanen T (2003) Democratization: A comparative analysis of 170 countries. Routledge, London and New York.

Wells S (2002) The Journey of Man: A Genetic Odyssey. Penguin Books, London. Zielonka J (2004) Challenges of EU Enlargement. Journal of Democracy 15(1):22-35. 